\title{
LOCALITY TRANSMISSION OF GLOBAL LUXURY BRANDS: CHANEL NO:5 PERFUME COMMERCIAL AND INTERCULTURALITY
}

\author{
Iş1 ZEYBEK \\ İstanbul Kültür Üniversitesi, Sanat ve Tasarım Fakültesi, İletişim Sanatları Bölümü \\ i.zeybek@iku.edu.tr
}

\begin{abstract}
ÖZET
Tüketicilerin doymak bilmeyen marka merakını, tatmin olmayan duygularını ve sürekli lüks tutkularını besleyen birçok reklam filmi bulunmaktadır. Elbette, konu lüks olunca bu reklam filmlerinin içinde, parfüm reklamlarının ne denli etkileyici ve büyüleyici bir düş dünyasında, tüketicilerini cezbedici ve 1şıltılı bir yolculuğu da çıkardıkları tartışılmazdır. Bir markanın, bir ürünün pazarlanması sürecinde uygulamaya sokulan stratejilerde değer olgusu, lüks markalara farklı anlamlar yüklemektedir. Günümüzde özellikle parfüm reklamlarında, az önce dile getirilen değer olgusunun kültürel göstergelerle aktarımına kimi zaman tanıklık edilmeye başlanmıştır. Bu bağlamda, çalışmanın ana konusunu, lüks tüketim sıralamasında yer alan Chanel No:5 parfümünün reklam filmi oluşturmaktadır. Söz konusu reklam filmi, Roland Barthes'in ortaya koyduğu göstergebilimsel çözümleme yöntemi doğrultusunda irdelenmeye çalışılacak ve kültürlerarası göstergelerin anlam düzeyinde etkisi ve ikna edici gücü ele alınmaya çalışılacaktır.
\end{abstract}

Anahtar sözcükler: Lüks marka, parfüm, tüketici, kültürel göstergeler, reklam

\begin{abstract}
There are multiple commercial films feeding the consumers' insatiable brand passion, unsatisfied emotions and constant passion for luxury. In the context of luxury, for sure it is uncontroversial that the commercial films, the impressive and enchanting imaginary world of the perfume commercials take their consumers to a charming and sheenful journey. Value phenomenon within the strategies employed during a brand's or a product's marketing process ascribe different meanings to luxury brands. Today, particularly in perfume commercials, transmission of value phenomenon mentioned above through cultural signs is witnessed. In this context, commercial film of Chanel No:5 perfume, listed in luxury consumption constitute the subject of this study. Concerned commercial will be analyzed with Roland Barthes' semiologic analysis method and impact of intercultural signs at meaning level and their persuasive power will be dealt with.
\end{abstract}

Keywords: Luxury brand, perfume, consumer, cultural signs, commercial

\section{INTRODUCTION}

Meeting the target audience despite the changes and innovations experienced everyday, the commercials preserve their existence as an act not losing its power and influence. This act intensely addresses the consumers in mass media sometimes and in digital environment at other times, as dynamic or constant messages, and proceeds its way in light of different purposes within the framework of different strategies. Proceeding, because commercials are one of the most effective media enabling communication between the consumers and brands. At this very point, presence and impact of the cultural agents, cultural signs that frequently become prominent in he global brands' commercials is seen as an undeniable element. When advertising communication and cultural signs are of issue, it is a well-known fact that values and lifestyles have recently come into prominence.

The values they hold are the most notable factors determining the behavior of the individuals living in the society. These values may be classified into three groups:

- Basic Values: Individual's beliefs and behavior concerning the position he/she desires to reach, 
- Domain-Specific Values: Beliefs concerning economic, social, religious and other activities,

- Evaluative Values: Values associated with the consumer's expectation from the product. (E.Vinson,E.Scott,L. Lamont:1977, 46)

In the process of advertising communication within the global sense, using merely values and lifestyles is not enough, and consumers' needs, expectations and motivations have to be taken into consideration. As is known, brands do not act merely on the values and lifestyles in their commercials. Consequently, signs building the commercial's relation with the concerned culture and society, which are called cultural signs, are of crucial importance. Symbols covering the words, actions, pictures and objects etc. that are specific to the culture, known by those sharing that culture and transmit various meanings (Hofstede,G.\&Hofstede,G.J,2005:9-11); characters or persons; traditions and ceremonial behavior (rituals); and values that are defined as a certain belief within the framework of a certain situation or belief, contrary to the attitudes concerning a specific purpose or situation (Mooji, M,2004:24) may be considered as cultural signs. Therefore, a sort of "locality" reference is possible in advertising communication. However, in this sense, strategies of the global brands are one of the most important criteria in creating the advertising message. Content, creators of the message and the lingual and visual signs used in the message will undergo a change, depending on the strategy of the brand. When the local actions of a global brand is considered, it is quite natural that the cultural signs of the country, where the commercial is to be broadcasted, are included. Therefore, communication respecting the creators of the concerned society, not ignoring these signs and where the message is structured based on these creators must form the basis of the advertising communication of the global brands. In this study, analysis of a global brand's advertising message transmitting the locality and with which signs it acts on globalism/locality line will be elaborated. Due to scientific reasons, the study had to be restricted, and in this sense, among the global brands, only those with "luxury" association were considered, and "sensory marketing", frequently discussed, studied on nowadays was taken as the sample. The sample was re-restricted and "perfume" commercials addressing our sense of smell and seeing have become the main focus.

For sure Chanel is one of the first brands to pop up in minds, when speaking of luxury brand and perfume brand: apparel, accessories, shoes, bag, perfume... "Chanel No: 5" is probably the first Chanel branded perfume to come to mind, with its haunting odor and as the perfume that is used by almost all women at least once. As Coco Chanel's first perfume and one of the world's best selling perfume, Chanel No: 5 is classified as an elegant, mild and floral perfume. It carries women away with its captivating influence and it is inevitable for all women to use this at least once in their life and experience joy and pleasure. One of the most important tools intermediating in this experience is advertising activities. At this point, perfume advertisements in mass media encountered as both moving and stable messages, are effective applications that attract target audience's interest, create desire to buy and "take them to a journey in the world of dreams."

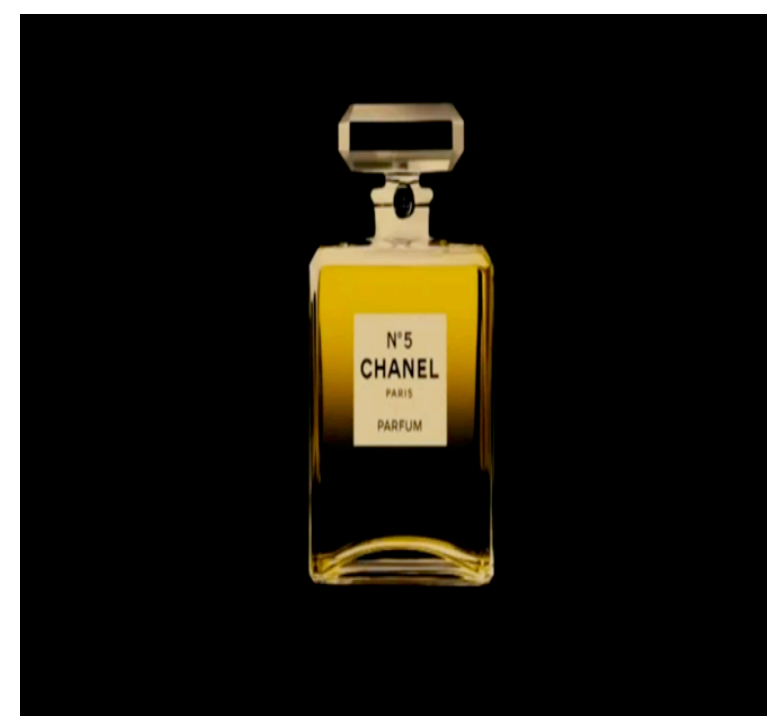




\section{STUDY METHOD}

Main purpose of this study is to elaborate on Chanel No: 5 perfume that is included in the world's luxury brands list in the context of persuasive advertising strategies and to analyze the concept of interculturality in advertising on the basis of advertising semiology, within the framework of advertisement/semiology/marketing. When visual analysis is of issue, the most important rule is to view the commercial message without any prejudice and to adopt the understanding that a single interpretation will not be valid alone. In this context, it is possible to make use of several methods in analyzing any visual. Analysis of advertising message is the analysis of a communication process. In this process, the message aims at transmitting a meaning. While creating the message, visual and lingual elements complement each other in meaning transmission. In Roland Barthes' words, "visual essence supports itself with a lingual message and reinforce the meaning" (Barthes, 1998: 189). This sentence means that the people make an analysis for the purpose of understanding the meaning as a result of text reading activity and that because the universe they analyze is a lingual, visual and moving commercial message, it is an "integrity of signs" consisting of audial intertwined signs.

Semiology is basically the science of analyzing all signs. It refers to making a sense of the lingual and visual elements within the text. This meaning attribution process also includes the act of meaning attribution realized in Roland Barthes' denotation sign and connotation level. Roland Barthes deals with the codes associated with the visual and aims at transmitting these codes to the units constituting the meaning. Barthes first separates visual and lingual elements of the visual, then considers these elements with denotation and connotation levels to reach a meaning. As is known, denotation emphasizes known meaning of the objects, forms and words, while connotation highlights the individuals' emotions, cultural values, perceptions and excitement. For Barthes, denotation is the level answering what is construed, whereas connotation answers how it is construed. (Küçükerdoğan,2011:193)

In this study, Roland Barthes' method that aims at reaching the meaning with binary oppositions and consists of denotation/connotation levels, with Barthes expressing the commercial as an interesting system, created by the unification of sound and writing and creating a "construing system (Rifat, 1998: $279)$ is taken as basis.

\section{ANALYSIS OF CHANEL NO:5 COMMERCIAL FILM}

Featuring Audrey Toutou and Travis Davenport, the commercial lasting 2 minutes and 25 seconds depicts a journey from Paris to Istanbul'a by Orient Express. This commercial film depicts a young and beautiful woman meeting a man during this train trip and this man's recognizing the woman from her fragrance and finding her in Haydarpaşa Terminal. In evaluating this legendary perfume's commercial film, considering remarkable images in terms of cultural signs would be appropriate:

Visual Signs: It is striking that images of Orient Express, Haydarpaşa Terminal, Bosporus, mosque, simit, ferry and Spice Bazaar are seen in the commercial film of the concerned legendary perfume. In the commercial, "Haydarpaşa Terminal" and "Bosporus", which are among Istanbul symbols, become prominent. 


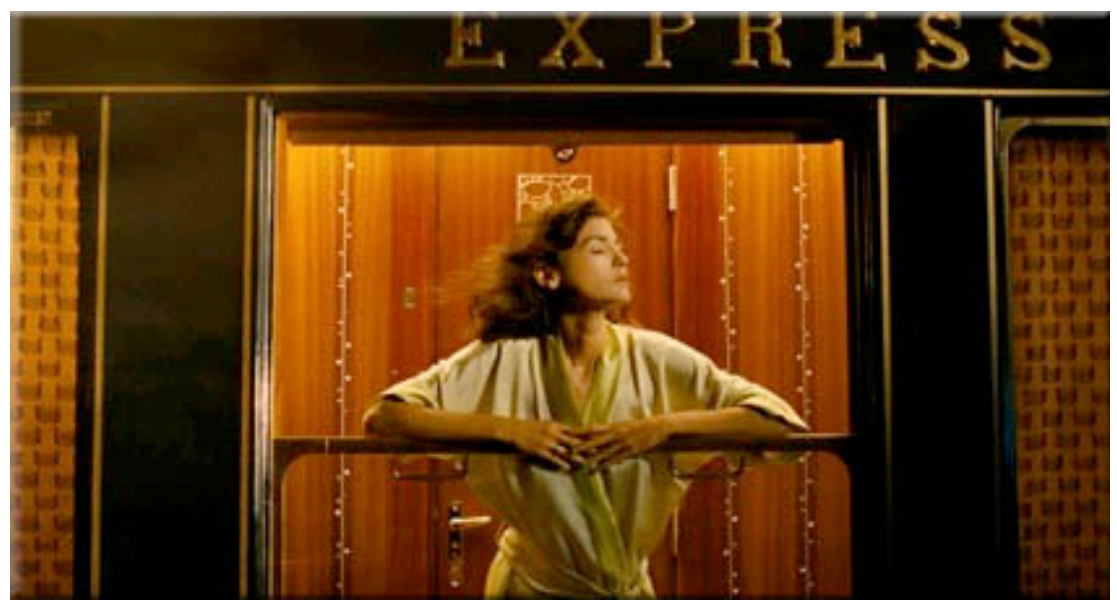

(www.astroturkiye.com)

Orient Express: It is a train designed in $19^{\text {th }}$ century for prosperous people to travel and complete a long journey in "luxury". The journey begins in Paris and lasts in Istanbul. "Orient Express" is a bridge, a symbol combining the east and west. Journey with Orient Express is the sign of a "privileged", "luxury", "prestigious" journey. All these meanings are ascribed to Chanel No:5.

Haydarpaşa Terminal: An old and historical venue, which is situated in Asian side Istanbul (Turkey) and of Istanbul's main terminal, is referred. The fundamental quality of this historical building is being Istanbul's first gate to Asia Minor and Middle East via railway. Therefore, Haydarpaşa Terminal is one of Istanbul's historical symbols. Additionally, this historical building is the symbol of the emotional pleasure, excitement and taste of arriving at Istanbul. In the commercial, in addition to the interior and exterior images of the historical building, the other images drawing the audience's attraction is Bosporus, ferry and seagulls.

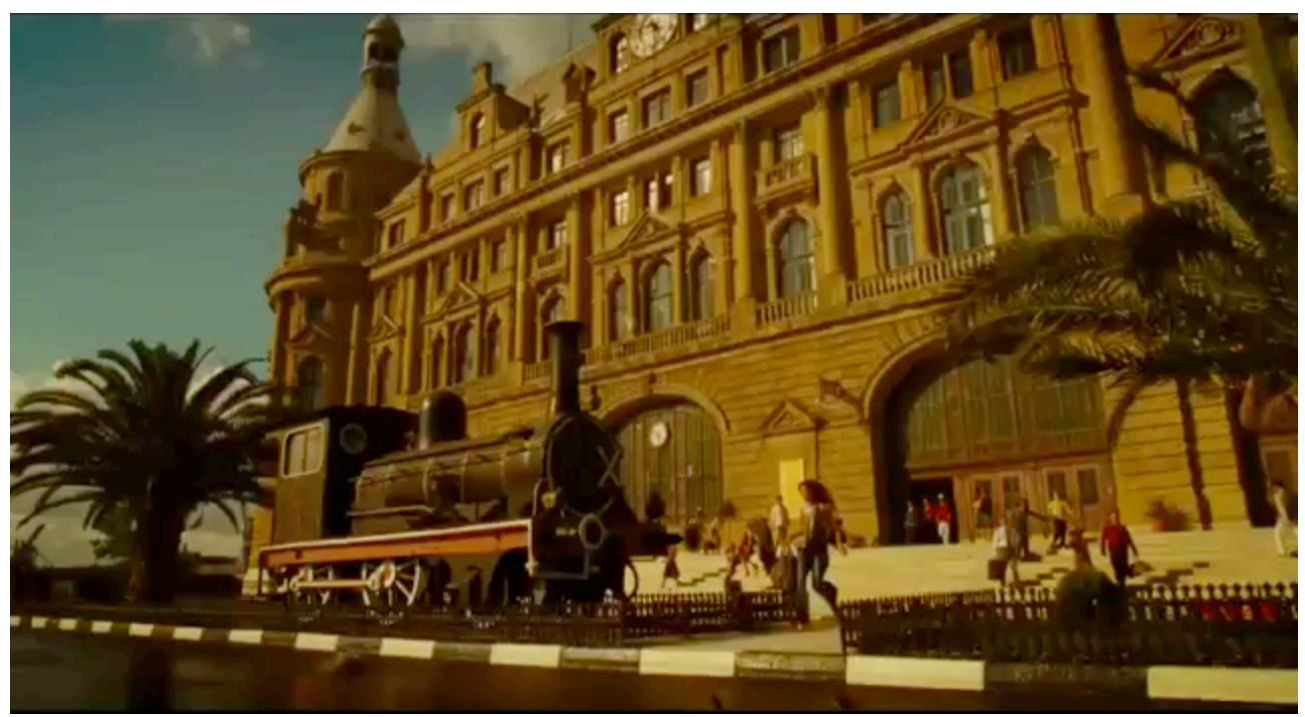

(www.astroturkiye.com)

Bosporus: Combining Asia and Europe, Bosporus has always been the world's special beauties both with its strategic location and its unique and magnificent view. It both divides Istanbul described as "Cradle of Civilizations" and combines/separates two continents. As one of the most well known signs describing and symbolizing Istanbul, Bosporus confronts us with its cultural sign quality. In the commercial, witnessing a moment from the train trip renders Bosporus an exceptional object combining Europe and Asia with Chanel No: 5. 


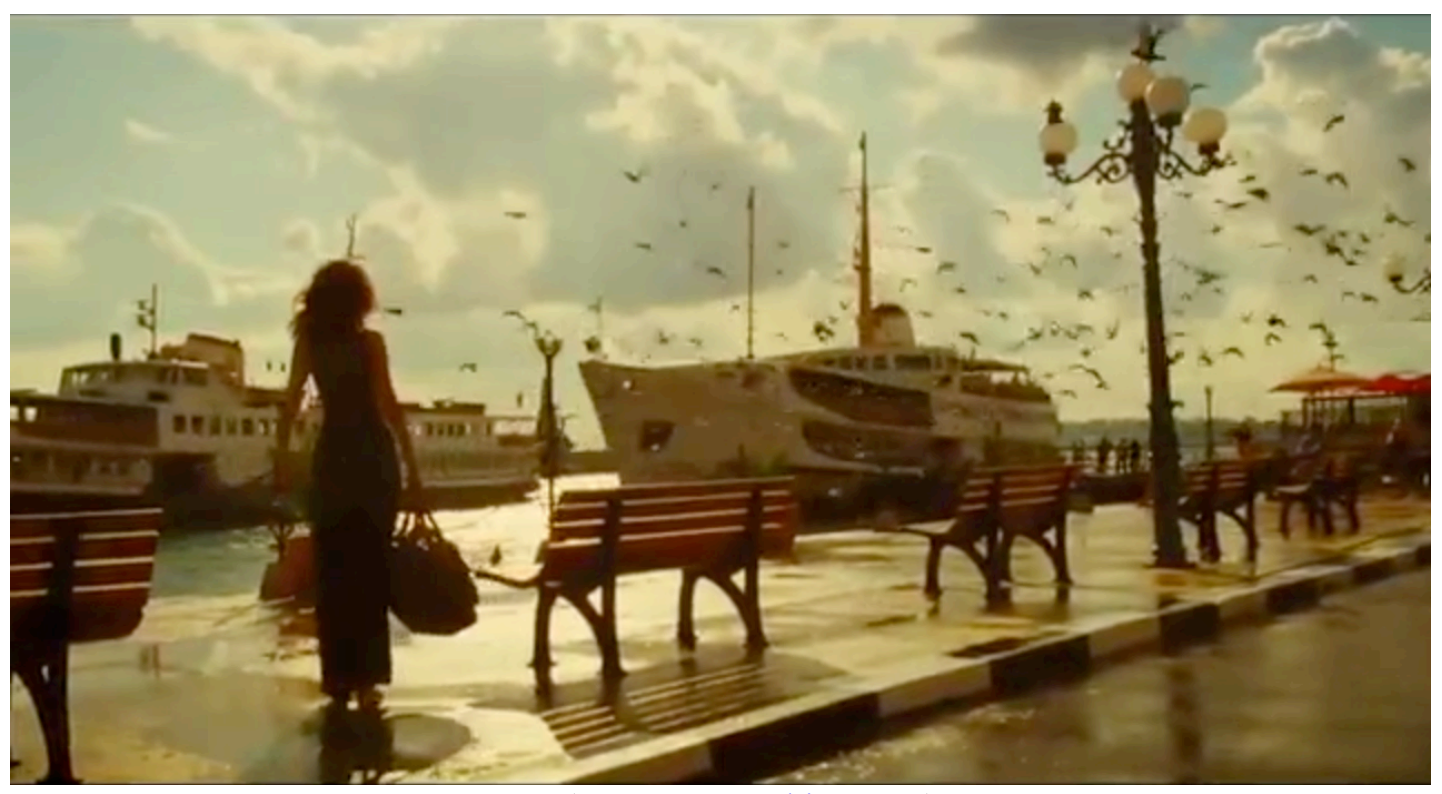

(www.astroturkiye.com)

Ferry: Speaking of "Istanbul" and "Turkey", ferries in Bosporus pop up in mind. Feeding seagulls during the ferry trip and watching them escorting the ferry enthusiastically are symbolic signs in the framework of Istanbul city life. Combined with the blue sky and bright sea, the magnificent view takes people to the world of dreams, and in other words, addresses getting away from the reality of life and perceiving texture, color and odor of Istanbul in a different way.

Seagulls: In Chanel No:5 commercial message, seagulls displayed with Bosporus and ferry images are the symbols of "freedom" and "Istanbul".

Spice Bazaar: Situated in Eminönü county, it is one of the oldest covered bazaars in Istanbul. As one of Istanbul's historical and cultural symbols, this bazaar offers natural, herbal medicines, spices, flower seeds and rare roots in particular. Spice Bazaar is a venue that represents both historical and symbolic features. It is an attractive and interesting place for the tourists. Therefore, Chanel No:5 communed in semiotic sense, with this historical and traditional space with both its fragrance and various flower and essence odors it contains.

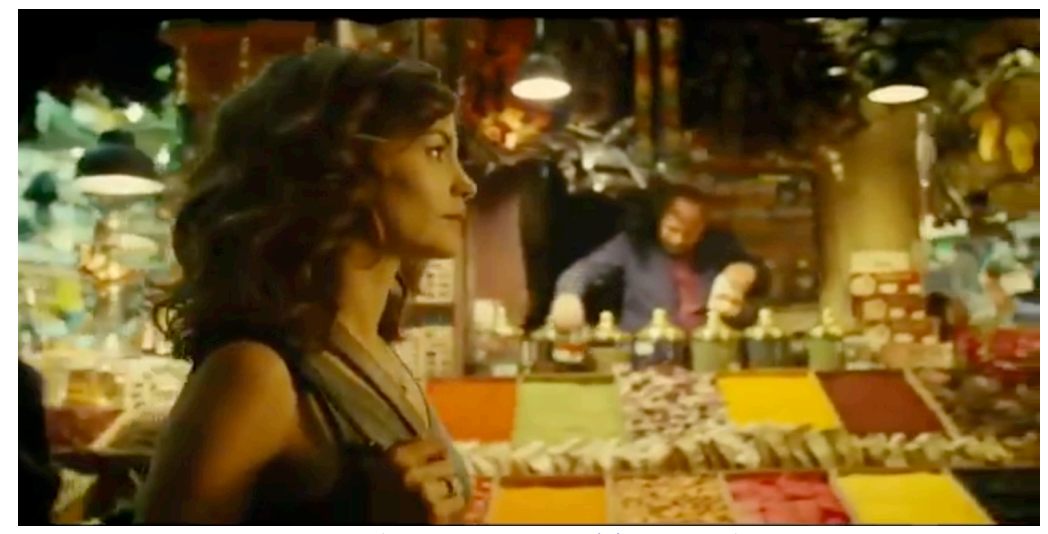

(www.astroturkiye.com)

Simit: It is the name of the sesame covered, round shaped bagel in Turkey. Produced commonly in Turkey, simit bears a symbolic quality within Istanbul lifestyle. It is a food sold particularly in simit shops or on the streets at all hours and consumed with a great pleasure. Additionally, simit's specific odor makes one's head swim and arouses the desire to eat one. Simit is a product that completely 
refers to Turkish culture. Although there are similar products in the other countries, simit is "specific" to us, it is unique. Just as Chanel No:5 perfume's original, unique and specific odor and this odor's influencing and dizzying people...

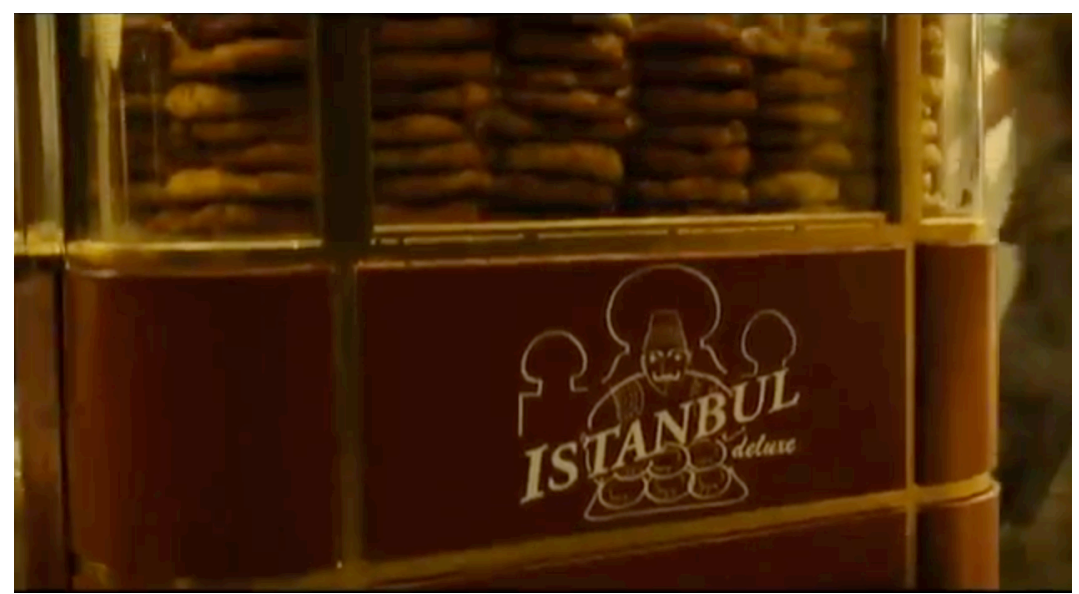

(www.astroturkiye.com)

Mosque: As the Muslim people's sacred praying venues, mosques confront us in the commercial with another important symbolic sign of Istanbul. These structures also bear wonderful beauties with their different forms and textures, in terms of their rich architecture and decorative elements. Mosque visual also refers to the beliefs.

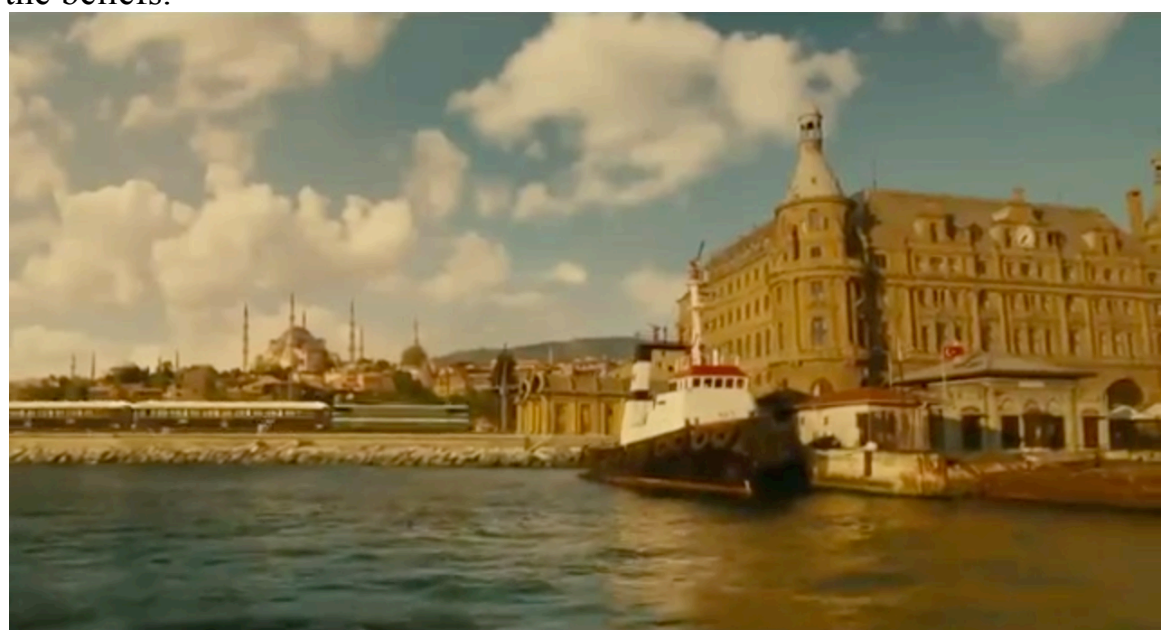

(www.astroturkiye.com)

In this commercial, with Haydarpaşa Terminal, Bosporus and Spice Bazaar images described as the cultural signs of Istanbul, as well as such visuals as ferry, simit and spices, symbolic elements of Istanbul are associated with Chanel No:5 perfume's symbolic value. In this context, symbolizing infinity, timelessness, persistency, unique beauty, existence, dream and power, Istanbul integrated Chanel No:5's feature of being golden oldie, keeping pace with any trend, being classical and traditional, as well as its dizzying effect with the perfume in visual sense.

Lingual Signs: When the commercial is taken as a whole, beyond lingual signs, Chanel No:5 perfume's bottle and logo are brought into the forefront. With the sentence "passeport s'il vous plait" (passport please) within the text, international travel, which emphasizes the perfume's global position, is highlighted. Moreover, in the simit scene within the commercial, the sign on the simit seller's trolley reading "Istanbul deluxe" not only indicates where the film is shot (space sign), but also luxury is connoted with "deluxe". Therefore, in the commercial, power of the visual signs, rather than lingual ones are intended to be used. 
Audio Signs: In the commercial, use of lingual signs is restricted. However, it can be said that the music, in other words audio signs not only reinforce the general content of the commercial, but also highlight the message of the commercial clearly. Moreover, the commercial also contains "sounds of the city", which can be depicted as audio signs. The sounds symbolizing the city, Istanbul include ferry horn, seagull yells and are heard throughout the commercial.

\section{CONCLUSION}

Commercial messages "addressing the subconscious", "directing", "persuading" through both lingual and visual techniques influence every aspect of our lives, in parallel with the concept of globalism. Because commercial messages are social facts, and important factors determining target audience's lifestyles, choices, behaviors and consumption habits, with their specific discourses. Roots of the term advertisement dates back to Medieval Latin and means "orienting someone's attention", and it is a process designing the way consumers perceive the product or service and the way to create any desired impact on them, and holding aesthetic function at the forefront.

In this context, main subject of this study is commercial film of Chanel No:5 perfume. When the film is considered as a whole, it attracts attention that the cultural signs are used in particular. It is also observed that cultural codes are used much within the commercials, particularly in perfume commercials. Therefore, now everyone witnesses how cultural codes, cultural signs turn into a very striking and imaginary journey in perfume commercials.

Based on making the consumers aware of the product characteristics and comparing it with the other brands, general marketing understanding has changed in the way to consider consumers' emotional, cognitive, behavioral experiences, and this where sensory/emotional marketing was born. Sensory/emotional brand creation and innovations in advertising strategies developed accordingly increase day by day. Sensory experiences are instantaneous, deeply affective, powerful experiences, and address five senses of the individuals or potential consumers. Perception of smell is the one that leaves the most emotional traces among all five senses. In this regard, it can be said that use of odor is one of the oldest marketing techniques. For example since old ages open air vendors had used incense sticks to draw the passer-by's attention to themselves. In this context, when advertising communication is of issue, it can be observed that odors can be connoted easily particularly through television. Because presentational value of the audiovisual devices and digital media is high, compared to the other tools. Perfume commercials, with the highest aesthetic function generally connote attractiveness, symbolic value, sexuality and passions. It would be appropriate to summarize the above stated connotations in a chart:

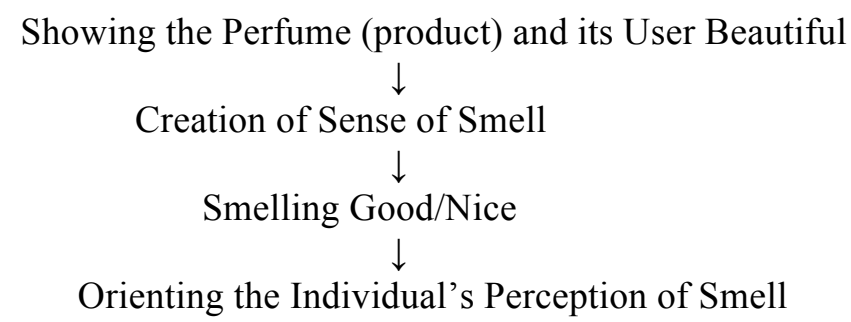

Given the universe of perfume is a sort of imaginary universe, it is essential that the advertising messages are created with aesthetical values. Therefore, beautiful bodies, beautiful faces, perfect, mystic, historical places are used. These uses attempt to sedate the consumer in a sense, with the message "buy this product, and you will experience the same". Messages of the perfume commercials are special as well, because a certain value is added to the perfume (Küçükerdoğan,2011:81-82-92-93). Within this framework, in Chanel No:5 commercial analyzed according to the method based on interpreting visual messages in the context of Roland Barthes' denotation and connotation, "interculturality" references are created at the level of both denotation and connotation and global/local opposition at the level of interpretation. When binary oppositions are pursued, "scent" connotations making reference to sensory marketing are present, and in the city (space) signs, Istanbul 
is highlighted in the context of locality. When a semiologic evaluation is made at the dimension of interculturality, below stated comparisons are seen:

\begin{tabular}{|l|l|}
\hline \multicolumn{1}{|c|}{ Denotation Axis } & \multicolumn{1}{c|}{ Connotation Axis } \\
\hline $\begin{array}{l}\text { Istanbul Visuals (Haydarpaşa Terminal- } \\
\text { Bosporus) }\end{array}$ & Chanel No:5 Perfume \\
\hline Smell of the Sea & Scent of the Perfume \\
\hline Historical place & An old and traditional perfume \\
\hline Bosporus combining Asia and Europe & A global brand \\
\hline Istanbul, a global brand city & A luxury brand \\
\hline Ferry symbolizing power & Perfume symbolizing existence and mystery \\
\hline $\begin{array}{l}\text { A city taking a magnificent view into the } \\
\text { forefront within timelessness }\end{array}$ & $\begin{array}{l}\text { A perfume taking mysterious femininity into the } \\
\text { forefront within timelessness }\end{array}$ \\
\hline City symbolizing dream & Perfume taking to the imaginary world \\
\hline
\end{tabular}

In creation of this universe of value, symbols and signs, particularly cultural signs transmitting "value", "elegance", "privilege" were used: Istanbul, Orient Express. With the advertising message of a classical and well-known luxury product, concerned "universe of values" is included in its own universe. With the advertisement message a "super language", a "super universe" was created.

In light of the above stated comparisons, with the cultural signs within the commercial film, Chanel No:5 perfume was brought to the consumers within a certain universe of values. In the advertisement message concerned, those to use the perfume are invited, called to become "the actors of a brilliant imaginary world" through cultural signs.

\section{REFERENCES}

Küçükerdoğan, R. (2011). Reklam Nasıl Çözümlenir, İstanbul: Beta Yayıncılık.

Barthes, R. (1998). Çağdaş Söylenler, İstanbul:Metis Yayınları.

Barthes, R. (1996). Göstergeler İmparatorluğu,İstanbul: YKY.

Gobé, M., (2009), Emotinal Branding, The New Paradigm for Connecting Brands to People, New York: Allworth Press.

Hofstede G. \& Hofstede G.J. (2005), Cultures and Organizations, Mc Graw Hill.

Mooij, M., (2004), Consumer Behaviour and Culture: Consequences for Global Marketing and Advertising, Sage Publications: California

Rifat, M., (1998), XX. Yüzyılda Dilbilimve Göstergebilim Kuramları: YKY Yayınları.

Vinson D.E., Scott E.J, Lamont M.L., (1977), "The role of Personal Values in Marketing and Consumer Behavior”, Journal Of Marketing. 